\title{
PDGFs Protect Hippocampal Neurons against Energy Deprivation and Oxidative Injury: Evidence for Induction of Antioxidant Pathways
}

\author{
Bin Cheng and Mark P. Mattson \\ Sanders-Brown Research Center on Aging and Department of Anatomy and Neurobiology, University of Kentucky, \\ Lexington, Kentucky 40536
}

Platelet-derived growth factors (PDGFs) and PDGF receptors are expressed in brain, where their functions are largely unknown. We tested the hypothesis that PDGFs play a role in promoting the survival of neurons exposed to metabolic and oxidative insults. Exposure of rat and mouse hippocampal cell cultures to glucose-deficient medium or the hydroxyl radical-promoting agent $\mathrm{FeSO}_{4}$ resulted in progressive neuronal loss. Pretreatment of cultures with PDGF-AA or PDGF-BB resulted in highly significant attenuation of glucose deprivation- and $\mathrm{FeSO}_{4}$-induced neuronal degeneration. In each injury paradigm the neuroprotective actions of the PDGFs were concentration dependent (3-100 $\mathrm{ng} / \mathrm{ml}$ ). In the case of glucose deprivation, significant protection was seen when cells were exposed to PDGFs prior to, or up to $\mathbf{8} \mathrm{hr}$ following, the onset of glucose deprivation. Pretreatment with PDGFs was required for protection against $\mathrm{FeSO}_{4}$-induced oxidative injury. Western blot and immunocytochemical analyses demonstrated that cultured embryonic hippocampal neurons expressed both PDGF $\alpha$ and $\beta$-receptors. PDGFs induced tyrosine phosphorylation of several proteins including a band at $180 \mathrm{kDa}$, the molecular weight of PDGF receptors. Induction of peroxide accumulation in neurons by $\mathrm{FeSO}_{4}$ was attenuated in cultures pretreated with PDGFs, suggesting that PDGFs enhanced cellular antioxidant mechanisms. Measurements of antioxidant enzyme activities in control and PDGF-treated cultures showed that both PDGF-AA and PDGF-BB increased both catalase and glutathione peroxidase activities, and PDGF-AA also increased superoxide dismutase activities. These findings suggest that PDGFs, which are widely expressed in brain and induced in response to injury, may play roles in protecting neurons against metabolic and oxidative insults.

[Key words: catalase, dichlorofluorescin, excitatory amino acid, glucose deprivation, glutathione peroxidase, hydroxyl radical, ischemic brain injury, peroxides, platelet-derived growth factor, superoxide dismutase, tyrosine kinase]

Received May 30. 1995; revised July 14, 1995; accepted July 20, 1995.

We thank J. G. Begley, S. Bosc, Y. Goodman, and M. A. Lovcll for technical assistance. This research was supported by grants to M.P.M. from the NIH (NS29001 and NS30583) and the Metropolitan Life Foundation.

Correspondence should be addressed to Mark P. Mattson, 211 SandersBrown Building, University of Kentucky, Lexington, KY 40536-0230.

Copyright $(\mathcal{C} 1995$ Society for Neuroscience $0270-6474 / 95 / 157095-10 \$ 05.00 / 0$
Platelet-derived growth factor (PDGF) is a polypeptide originally identified based on its potent mitogenic effect on mesenchymal cells such as vascular endothelial cells and fibroblasts (see Ross et al., 1986; Williams, 1989, for review). PDGF is encoded by two genes which give rise to PDGF-A and PDGF-B chains, with the active growth factor being homodimeric (AA or BB) or heterodimeric (AB). Two different plasma membrane receptors for PDGF have been identificd; the $\alpha$-receptor binds all forms of PDGF whereas the $\beta$-receptor binds only PDGF dimers containing $\mathrm{B}$ chains (Claesson-Welsh, 1988; Heldin et al., 1989; Matsui et al., 1989; Seifert et al., 1989). PDGF has been shown to influence the proliferation and differentiation of oligodendrocytes (Noble et al., 1988; Raff et al., 1988) and may have chemotactic activity towards astrocytes (Bressler et al., 1985). In addition, PDGF increased the cellular volume of intraocular parietal and hippocampal grafts which appeared to be due mainly to increased astrocytes (Giacobini et al., 1992). Recent data suggest that PDGF may also affect neurons. For example, Smits et al. (1991) reported that PDGF-BB induced c-Fos expression and promoted long-term survival in cultured brain neurons, and Nikkhah et al. (1993) reported that PDGF promoted long-term survival of cultured mesencephalic dopaminergic neurons.

PDGF and PDGF receptors appear to be widely distributed in brain. PDGF-B and PDGF-A chain mRNAs are expressed in neurons throughout the brains of monkey and mice (Sasahara et al., 1991), and PDGF-B chain immunoreactivity was localized to neurons in several brain regions including the hippocampus (Sasahara et al., 1992). In the mouse, each isoform of PDGF is expressed in the developing brain where they are localized to neurons and growth cones (Hutchins and Jefferson, 1992). The PDGF $\beta$-receptor is expressed at high levels in the mouse forebrain during embryonic and early postnatal development (Hutchins and Jefferson, 1992), and PDGF $\beta$-receptor immunoreactivity localizes to retinal ganglion neurons (Hutchins and Zhang, 1994). In situ hybridization studies have shown that PDGF $\alpha$-receptor mRNA in brain is expressed largely in glial cells during development of mouse and rat (Pringle et al., 1992; Yeh et al., 1993). Expression of each of the PDGF receptors in brain is greater in late embryonic and early postnatal period than in the adult (Reddy and Pleasure, 1992). Neuroblastoma cells express both PDGF $\alpha$ - and $\beta$-receptors, and activation of each of these receptors appears to induce neurite outgrowth (Matsui et al., 1993). The mechanisms regulating expression of PDGFs and their receptors in brain are largely unknown, although it has been 

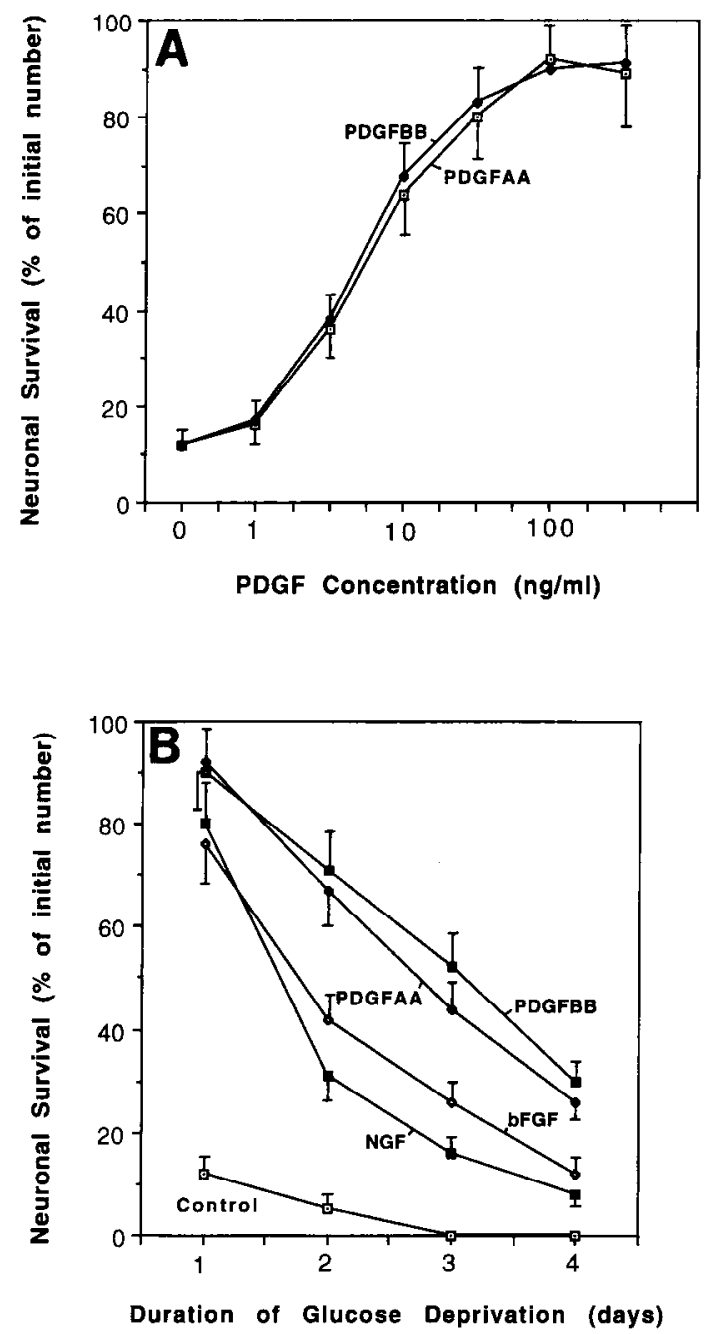

Figure 1. Concentration dependence and time course of PDGF protection against glucose deprivation-induced neuronal death. A, Hippocampal cultures were pretreated for $24 \mathrm{hr}$ with the indicated concentrations of PDGF-AA or PDGF-BB. Cultures were then deprived of glucose for $24 \mathrm{hr}$ and neuronal survival was quantified. Values represent the mean and SEM of determinations made in 4 separate cultures. Survival was significantly greater in PDGF-treated cultures with PDGF concentrations of $5 \mathrm{ng} / \mathrm{ml}(p<0.05)$, and $10,50,100$, and $300 \mathrm{ng} / \mathrm{ml}$ $(p<0.001)$. B. Cultures were pretreated for 24 hir with the indicated factors (PDGF-AA and PDGF-BB, $100 \mathrm{ng} / \mathrm{ml}$; bFGF and NGF, $10 \mathrm{ng} /$ $\mathrm{ml}$ ) or vehicle (control). Cultures were then deprived of glucose and neuronal survival was assessed at $24 \mathrm{hr}$ intervals during a $4 \mathrm{~d}$ period. Values represent the mean and SEM of determinations made in four separate cultures. Survival was significantly greater in cultures treated with PDGF-AA, PDGF-BB, bFGF, and NGF at $1 \mathrm{~d}(p<0.001)$, PDGF$\mathrm{AA}$ and PDGF-BB at $2 \mathrm{~d}$ and $3 \mathrm{~d}(p<0.001)$, bFGF and NGF at $2 \mathrm{~d}$ and $3 \mathrm{~d}(p<0.01)$, PDGF-AA and PDGF-BB at $4 \mathrm{~d}(p<0.01)$, bFGF and NGF at $4 \mathrm{~d}(p<0.05)$.

established that brain injury can induce expression of PDGF-B chain (Iihara et al., 1994).

Several mitogenic growth factors have neurotrophic activities towards CNS neurons. For example, basic fibroblast growth factor (bFGF) supported long-term survival of neocortical neurons (Morrison et al., 1986) and protected hippocampal and neocortical neurons against excitotoxic and metabolic insults (Mattson et al., 1989; Cheng and Mattson, 1991). Neurotrophin-3 and BDNF protected hippocampal, septal, and neocortical neurons against glucose deprivation-induced injury (Cheng and Mattson,

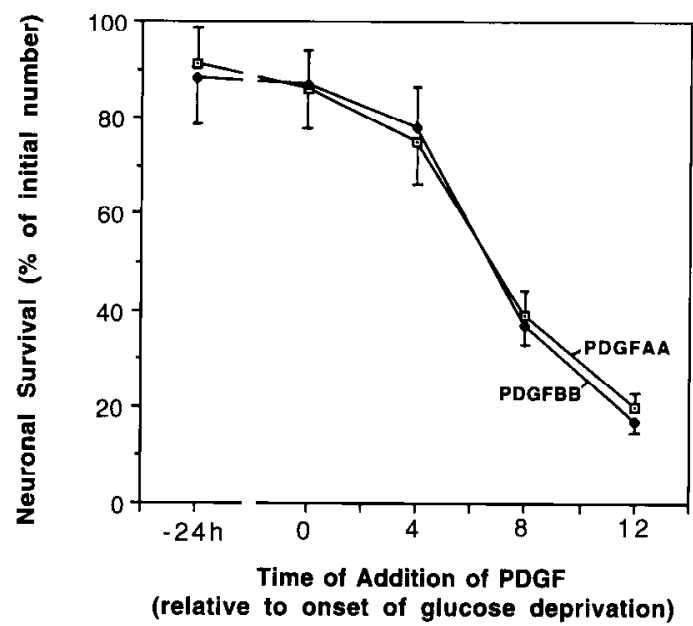

Figure 2. Relationship between the time of addition of PDGFs, relative to the onset of glucose deprivation, and efficacy in protecting against neuronal death. Hippocampal cultures were exposed to PDGFAA or PDGF-BB $(100 \mathrm{ng} / \mathrm{ml})$ at the indicated time points relative to the onset of glucose deprivation $(t=0$ is the time of glucose deprivation). Neuronal survival was quantified $24 \mathrm{hr}$ following the onset of glucose deprivation. Values represent the mean and SEM of determinations made in four separate cultures.

1994), and tumor necrosis factors protected cultured hippocampal neurons against excitotoxic insults (Cheng et al., 1994). The rapidly growing body of data on neurotrophic factors and brain injury demonstrates that brain injury induces the expression of several different trophic factors (e.g., bFGF, NGF, BDNF, and TGF $\beta$ ), some of which can protect neurons against excitotoxic, metabolic and oxidative insults (see Mattson et al., 1993a, for review). While recent studies have revealed potential roles for some neurotrophic factors in neural injury, it is not known whether PDGF influences neuronal survival in such conditions.

Accumulating data implicate the involvement of free radicals in the neuronal injury that occurs in an array of neurodegenerative conditions ranging from acute insults such as traumatic brain injury and stroke, to chronic neurodegenerative disorders such as Alzheimer's disease and amyotrophic lateral sclerosis (see Watson and Ginsberg, 1989; Hall et al., 1991; Mattson, 1994; Brown, 1995, for review). Under conditions of ischemia free radicals arise from altered mitochondrial function, inositol phospholipid metabolism and elevation of intracellular calcium levels. The primary alterations contributing to free radical production are likely to differ among neurodegenerative disorders. For example, in Alzheimer's disease the $\beta$-amyloid peptide is implicated (Goodman and Mattson, 1994; Hensley et al., 1994), while in amyotrophic lateral sclerosis alterations in the antioxidant enzyme $\mathrm{Cu} / \mathrm{Zn}$-superoxide dismutase may play a causal role (Brown, 1995). In light of recent data indicating that neurotrophic factors can increase antioxidant defense mechanisms in neurons (see Mattson et al., 1993a, for review), we tested the hypothesis that PDGFs increase activity of antioxidant enzymes and increase resistance to oxidative insults.

\section{Materials and Methods}

Hippocampal and neocortical cell cultures. Hippocampi and neocortical hemispheres were removed from embryonic day 18 Sprague-Dawley rats or embryonic day $16 \mathrm{C} 57 \mathrm{BL} / 6$ mice (Harlan, Inc.). Cells were dissociated by mild trypsination and trituration as described previously (Mattson et al., 1995a) and were seeded into polyethyleneimine-coated plastic (for cell survival analysis) or glass-bottom (for cellular peroxide 


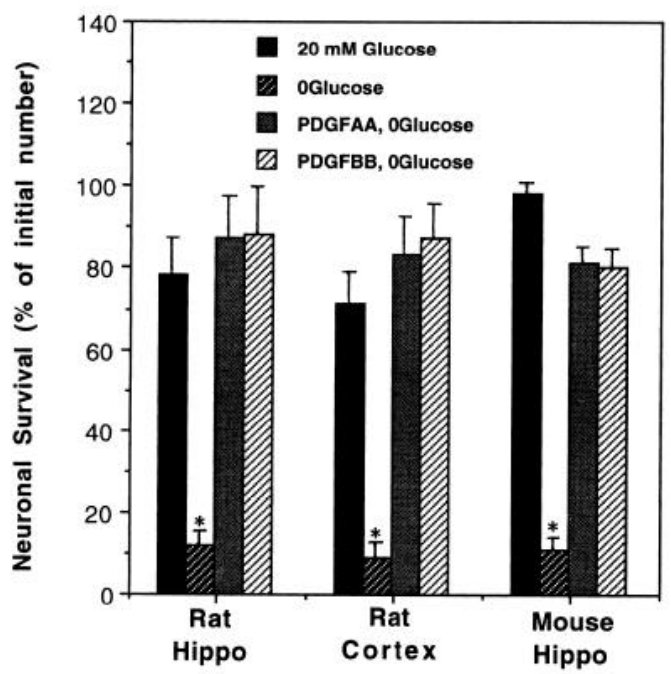

Figure 3. PDGFs protect cultured rat and mouse hippocampal and rat neocortical neurons against glucose deprivation-induced injury. Cultures were pretreated for $24 \mathrm{hr}$ with saline (OGlucose) or $100 \mathrm{ng} / \mathrm{ml}$ PDGF-AA or PDGF-BB. Cultures were then deprived of glucose for $24 \mathrm{hr}$ (rat hippocampus and neocortex) or $12 \mathrm{hr}$ (mouse hippocampus). Values represent the mean and SEM of determinations made in four separate cultures. ${ }^{*}, p<0.001$ compared to corresponding values for cultures containing glucose, PDGF-AA, or PDGF-BB.

measurements) $35 \mathrm{~mm}$ culture dishes, or $60 \mathrm{~mm}$ plastic culture dishes (for Western blot analyses and antioxidant enzyme activity assays) containing Eagle's Minimum Essential Medium supplemented with $26 \mathrm{~mm}$ $\mathrm{NaHCO}_{3}, 40 \mathrm{~mm}$ glucose, $20 \mathrm{~mm} \mathrm{KCl}, 1 \mathrm{~mm}$ sodium pyruvate, $10 \%$ $(\mathrm{v} / \mathrm{v})$ heat-inactivated fetal bovine serum (Sigma), and $0.001 \%$ gentamicin sulfate. After a 3-5 hr incubation period to allow for cell attachment, the medium was replaced with either $0.8 \mathrm{ml}$ (35 mm dishes) or $1.5 \mathrm{ml}$ ( $60 \mathrm{~mm}$ dishes) of fresh medium. Cultures were maintained in a humidified atmosphere $\left(6 \% \mathrm{CO}_{2}, 94 \%\right.$ room air $)$ at $37^{\circ} \mathrm{C}$. All experiments were performed in 7-10 d old cultures; at this time in culture approximately $85-90 \%$ of the cells were neurons and the remaining cells were astrocytes (Mattson et al., 1995a).

Experimental treatments. Methods for glucose deprivation and exposure to $\mathrm{FeSO}_{4}$ are detailed in our previous studies (Cheng and Mattson, 1991; Zhang et al., 1993; Mattson et al., 1995a). For glucose deprivation, cultures were washed three times with glucose-free Locke's solution (154 mM NaCl, $5.6 \mathrm{~mm} \mathrm{KCl,} 2.3 \mathrm{~mm} \mathrm{CaCl}_{2}, 1.0 \mathrm{~mm} \mathrm{MgCl}_{2}$, $3.6 \mathrm{~mm} \mathrm{NaHCO}, 5 \mathrm{~mm}$ HEPES) and then incubated in $1 \mathrm{ml}$ of the same solution. Glucose-containing $(20 \mathrm{~mm})$ Locke's solution was used in parallel control cultures. For exposure to $\mathrm{FeSO}_{4}$, cultures were washed twice with glucose-containing Locke's solution and then incubated in $1 \mathrm{ml}$ of the same medium. $\mathrm{FeSO}_{4}$ was prepared as a $500 \times$ stock in sterile water and was diluted directly into the culture medium. Recombinant human PDGF-AA and PDGF-BB were purchased from Austral Biologicals (San Ramon, CA), and bovine recombinant bFGF and human recombinant NGF were purchased from Boehringer Mannheim (Indianapolis, IN). PDGFs and other neurotrophic factors were included in the glucose-deficient medium. Neuronal survival was quantified by photographing the same $10 \times$ microscope fields (phase-contrast) immediately prior to, and at appropriate time points following, glucose deprivation or exposure to $\mathrm{FeSO}_{4}$. Neurons were considered viable if they had neurites that were uniform in diameter and smooth in appearance, and somata that were smooth and round to oval in shape. Degenerating nonviable neurons had fragmented and beaded neurites, and a swollen and vacuolated soma with an irregular shape. Subsequent to these morphological changes, the degenerated neurons detached from the culture substrate. Cell counts were made directly from photographic negatives without knowledge of the treatment history of the cultures. Statistical comparisons were done using paired and unpaired Student's $t$ tests (two-tailed), or one-way analysis of variance (ANOVA) and Scheffe's post hoc test for pairwise comparisons.

Immunocytochemistry and Western blot analysis. These methods were essentially identical to those used in our past studies (Mattson et al., 1993b; Cheng et al., 1994). For Western blot analysis cultured cells
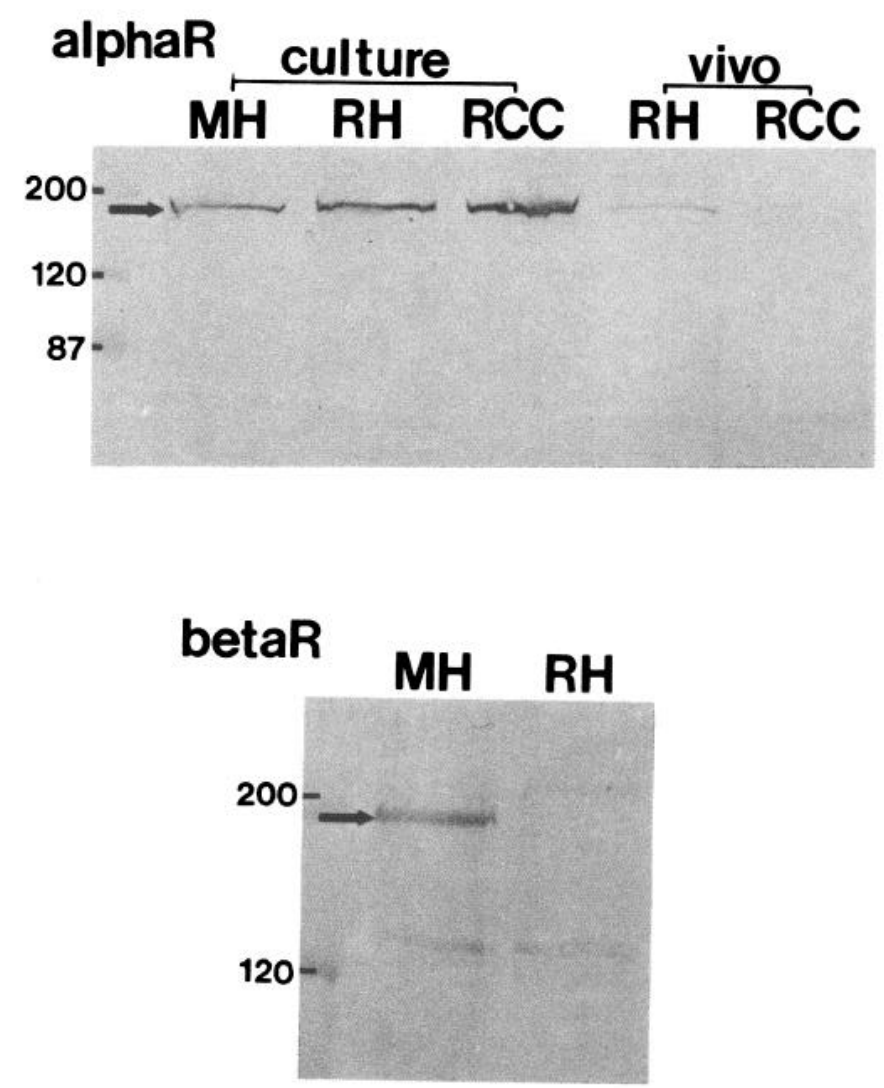

Figure 4. Western blot analysis of PDGF receptor expression in hippocampal and cortical cells. Equivalent amounts of protein $(50 \mu \mathrm{g}$ for PDGF $\alpha$-receptor and $100 \mu \mathrm{g}$ for PDGF $\beta$-receptor) were separated by SDS-PAGE (7.5\% SDS), transferred to nitrocellulose and immunoblotted. Upper panel, immunoblot probed with an antibody that recognizes both rat and mouse PDGF $\alpha$-receptor (alphaR). $M H$, Mouse hippocampus; $R H$, rat hippocampus; $R C C$, rat cerebral cortex; vivo, tissue from adult rat brain. Note single immunoreactive band at approximately 180 $\mathrm{kDa}$ in cultured cells; this band was faint or absent in tissue taken from adult rat brain. Lower panel, immunoblot probed with an antibody to the mouse PDGF $\beta$-receptor $($ betaR). The lanes contained cell homogenates from mouse hippocampal $(M H)$ or rat hippocampal $(R H)$ cell cultures. Note immunoreactive band at approximately $180 \mathrm{kDa}$ in mouse hippocampal cultures which is not detected by this antibody in rat hippocampal cultures.

were scraped from $60 \mathrm{~mm}$ dishes in sample buffer ( 2 mM EDTA, 2.3\% SDS, $10 \%$ glycerol, and $62 \mathrm{~mm}$ Tris, $\mathrm{pH} 6.8$ ), while hippocampal and neocortical tissue from adult rat brain was homogenized in a buffer containing a cocktail of protease inhibitors. For antiphosphotyrosine immunoblot analysis, cultures were incubated for $10 \mathrm{~min}$ in the presence of $1 \mathrm{~mm}$ sodium orthovanadate prior to exposure to PDGFs. Protein was separated by SDS-PAGE ( 7.5 or $10 \%$ acrylamide), transferred to nitrocellulose sheets, and blocked with $5 \%$ milk. The nitrocellulose was then incubated sequentially in solutions containing primary antibody, alakaline phosphatase-conjugated secondary antibody (Vector Laboratories), and alkaline phosphatase substrate developer (Vector Labs). For immunocytochemistry, cultures were fixed for $30 \mathrm{~min}$ in cold $4 \%$ paraformaldehyde in $10 \mathrm{~mm}$ PBS, permeabilized by incubating for $5 \mathrm{~min}$ in a $0.2 \%$ solution of Triton X-100 in phosphate-buffered saline (PBS), and incubated for $30 \mathrm{~min}$ in blocking serum (normal goat or horse serum). Cells were then incubated sequentially in primary antibody ( 3 hr), biotinylated secondary antibody (1 hr), and FITC-avidin (30 min). Images of cellular immunofluorescence were acquired with a confocal laser scanning microscope (Molecular Dynamics), and photographs were taken directly from the video monitor. The primary antibodies employed were: a rabbit polyclonal antibody to the human PDGF $\alpha$-receptor which recognizes both rat and mouse PDGF $\alpha$-receptor (Upstate Biotechnology, Inc., Lake Placid, NY); a rabbit polyclonal antibody to the mouse PDGF $\beta$-receptor which exhibits little or no cross-reactivity 

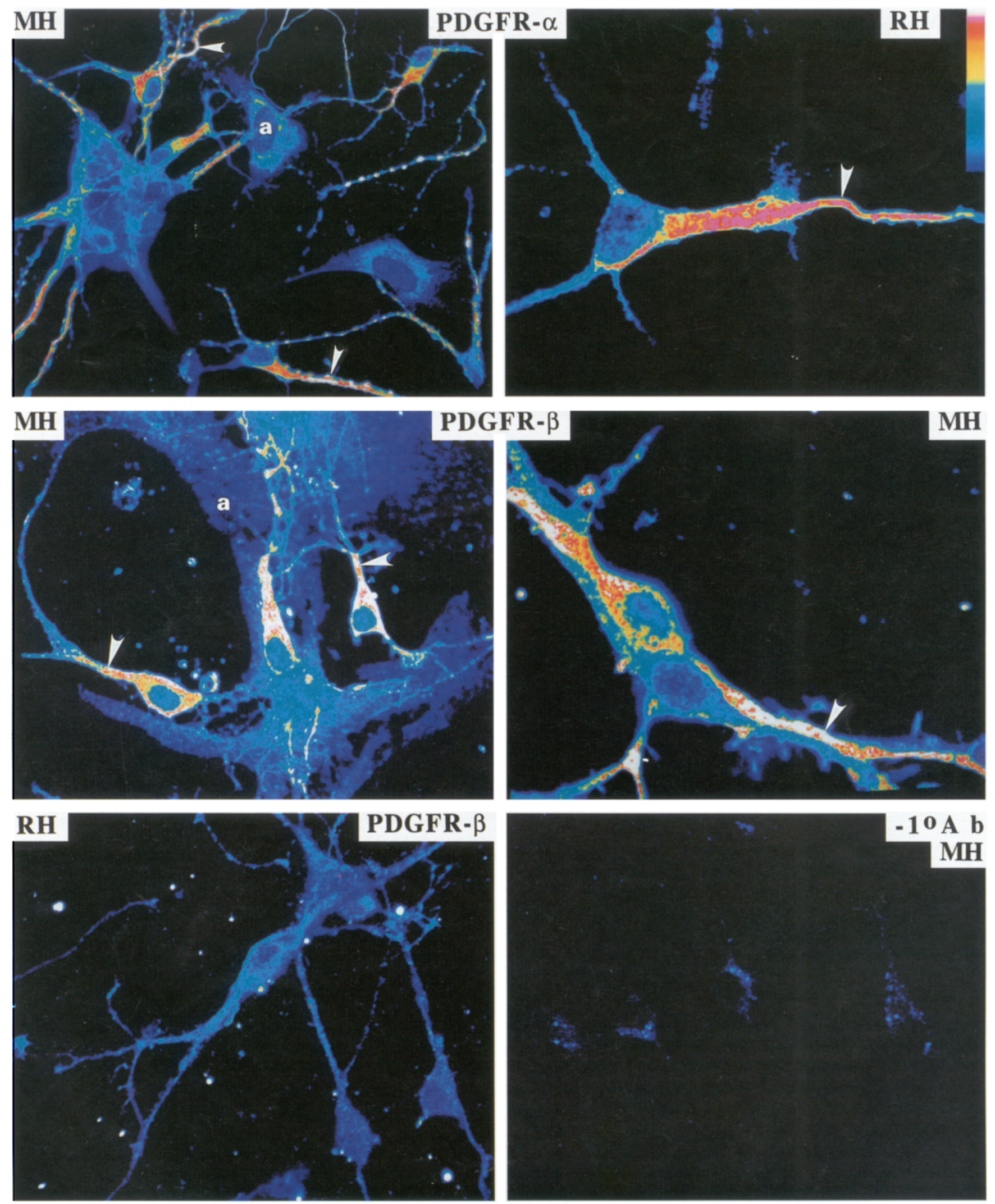

Figure 5. Immunocytochemical localization of PDGF receptors in hippocampal cell cultures. Cultures from mouse hippocampus $(M H)$ or rat hippocampus $(M H)$ were immunostained with antibodies to either the PDGF $\alpha$-receptor $(P D G F R-\alpha)$ or the PDGF $\beta$-receptor $(P D G F R-\beta)$. Immunofluorescence images of cells were acquired with a confocal laser scanning microscope. Relative levels of immunoreactivity are represented by the color scale shown in the upper right panel wherein colors represent pixel intensity (on a scale from 0 to 256 ; blue is the lowest level of fluorescence and white the highest level). Upper panels, PDGFR- $\alpha$ immunoreactivity was present in neurons where it was particularly concentrated in cell bodies and proximal regions of axons (arrowheads). PDGFR- $\alpha$ immunoreactivity was also present in astrocytes (a). Middle panels, PDGFR- $\beta$ immunoreactivity was present in mouse hippocampal neurons where it was particularly concentrated in cell bodies and proximal regions 
with rat PDGF $\beta$-receptor (Becton Dickinson, Beford, MA); and a mouse monoclonal antibody that recognizes proteins phosphorylated on tyrosine residues (clone 4G10; Upstate Biotechnology). Antibodies were used at dilutions of $1: 1000$ to $1: 200$.

Measurement of cellular peroxides. Relative levels of cellular peroxides were quantified by confocal laser scanning microscope analysis of cultured neurons loaded with the dye 2,7-dichlorofluorescin diacetate as described previously (Goodman and Mattson, 1994; Mattson et al., 1995a). The dye is converted to the fluorescent compound 2,7-dichlorofluorescein (DCF) upon interaction with peroxides (Page et al., 1993) Cells were incubated for $50 \mathrm{~min}$ in the presence of $50 \mu \mathrm{M}$ of the dye, and were then washed three times ( $2 \mathrm{ml} /$ wash) in Hanks' Balanced Saline Solution containing $10 \mathrm{~mm}$ Hepes buffer and $10 \mathrm{~mm}$ glucose. Imaging studies employed a confocal laser scanning microscope (Molecular Dynamics, Sarastro 2000) coupled to an inverted microscope (Nikon). The dye was excited at $488 \mathrm{~nm}$ and emission was filtered using a $510 \mathrm{~nm}$ barrier filter. The intensity of the laser beam and the sensitivity of the photodetector were held constant to allow quantitative comparisons of relative fluorescence intensity of cells between treatment groups. Cells were located under visible light and scanned only once with the laser because preliminary studies revealed that exposure to the lase light could itself induce photo-oxidation resulting in increased DCF fluorescence. Staining intensity/cell was quantified using Molecular Dynamics IMAGESPACE software.

Antioxidant enzyme activity assays. Activities of $\mathrm{Cu} / \mathrm{Zn}-\mathrm{SOD}, \mathrm{Mn}$ SOD, catalase, and glutathione peroxidase (GSHPx) in cultured cells were quantified by methods based upon those of Mizuno (1984). Cells from eight $60 \mathrm{~mm}$ culture dishes were pelleted by low-speed centrifugation and homogenized in $2.5 \mathrm{ml}$ of a nitrogen-purged buffer consisting of $10 \mathrm{~mm}$ Hepes, $137 \mathrm{~mm} \mathrm{NaCl}, 4.6 \mathrm{mM} \mathrm{KCl}, 1.1 \mathrm{mM} \mathrm{KH} \mathrm{KO}_{4}, 0.6$ $\mathrm{mM} \mathrm{MgSO}{ }_{4}, 0.6$ (pH 7.4). The homogenate was centrifuged for $1 \mathrm{hr}$ at $100,000 \times g$ at $4^{\circ} \mathrm{C}$ and the supernatant used for enzyme assays. For the SOD activity assay, $200 \mu \mathrm{l}$ of the supernatant was added to 1.48 $\mathrm{ml}$ of $68 \mathrm{~mm} \mathrm{NaH}, \mathrm{PO}_{+}$containing $1.35 \mathrm{~mm}$ EDTA (pH 7.8), $100 \mu \mathrm{l}$ of $4 \mathrm{~mm}$ xanthine, and $170 \mu \mathrm{l}$ of 3.53 mm epinephirime ( $\mathrm{pH}$ । 1.5). After a 5 min incubation at $30^{\circ} \mathrm{C}, 50 \mu \mathrm{J}$ of xanthine oxidase was added to the cuvette and the absorbance was followed for $3 \mathrm{~min}$ at $320 \mathrm{~nm}$. To control for variability among lots, xanthine oxidase was diluted until an assay mixture without SOD yielded $0.03 \mathrm{~A}$ change/min. MnSOD activity was taken as the SOD activity remaining following addition of potassium cyanide $(200 \mathrm{~mm})$. One unit of SOD activity was defined as the amount that reduced the absorbance change by $50 \%$, and results were expressed as units/mg protein. For the catalase activity assay, cell homogenate supernatant $(1.5 \mathrm{ml})$ was mixed with $18 \mu \mathrm{l}$ of absolute ethanol. incubated on ice for $8 \mathrm{~min}$, and $7.8 \mu \mathrm{l}$ of $10 \%$ Triton X-100 and $2.5 \mathrm{ml} 10 \mathrm{~mm} \mathrm{NaH} \mathrm{PO}_{4}$ buffer $(\mathrm{pH} 7.4)$ were added. Aliquots $(0.6 \mathrm{ml})$ of the solution were added to $20 \mathrm{ml}$ test tubes along with $3.57 \mathrm{ml}$ of cold $6 \mathrm{~mm}$ hydrogen peroxide and the tube was vortexed. After $3 \mathrm{~min}$, $0.714 \mathrm{ml}$ of $6 \mathrm{~N} \mathrm{H}_{2} \mathrm{SO}_{4}$ was added and the mixture vortexed. Five milliliters of $0.01 \mathrm{~N} \mathrm{KMnO}_{4}$ was added to the solution, the tube vortexed and the absorbance measured at $480 \mathrm{~nm}$ within $60 \mathrm{sec}$ using a Spec 21 UV-Vis spectrophotometer. Quantitation was based on the comparison of the tissue samples to a calibration curve of known peroxide concentrations. The activity of the enzyme was expressed as units $/ \mathrm{mg}$ protein with 1 unit $=1 \mu \mathrm{mol}$ of $\mathrm{H}_{2} \mathrm{O}_{2}$ catalyzed $/ \mathrm{min}$. GSHPx activity was determind by quantifying the rate of oxidation of reduced glutathione to oxidized glutathione by $\mathrm{H}_{2} \mathrm{O}_{2}$ as catalyzed by the GSHPx present in the cell homogenate supernatant. The assay measured the decrease in absorbance at $340 \mathrm{~nm}$ as NADPH was converted to NADP (1 unit of activity $-1 \mathrm{nmol} \mathrm{N} A \mathrm{DPH}$ oxidized/min). The blank for each enzyme assay contained cell homogenate supernatant which had been heated at $100^{\circ} \mathrm{C}$ for $5 \mathrm{~min}$.

\section{Results}

PDGF-AA and PDGF-BB protect cultured hippocampal neurons against glucose deprivation-induced injury Hippocampal cell cultures were pretreated for $24 \mathrm{hr}$ with increasing concentrations of either PDGF-AA or PDGF-BB, or saline (control), and were then deprived of glucose for $24 \mathrm{hr}$. In control glucose-deprived cultures fewer than $15 \%$ of the neurons survived the $24 \mathrm{hr}$ period of glucose deprivation (Fig. 1A). In contrast, neuronal survival was significantly increased in cultures pretreated with PDGF-AA and PDGF-BB at concentrations of $5-300 \mathrm{ng} / \mathrm{ml}$. The protective action of PDGFs was directly related to concentration of the growth factor with concentrations of 100 and $500 \mathrm{ng} / \mathrm{ml}$ providing maximum neuronal survival of approximately $90 \%$ (Fig. 1A). The concentration-effect curves for PDGF-AA and PDGF-BB were very similar. In order to determine how long PDGF-treated neurons remained viable in the absence of glucose, neuronal survival was monitored during a $4 \mathrm{~d}$ period of glucose deprivation (Fig. $1 B$ ). Whereas essentially all neurons died within $3 \mathrm{~d}$ of glucose withdrawl in control cultures, approximately $50 \%$ of the neurons remained viable at this time point in cultures treated with either PDGF-AA or PDGF-BB. More than $30 \%$ of the neurons in PDGF-treated cultures were viable at $4 \mathrm{~d}$ following glucose withdrawl (Fig. 1B). As with the concentration-effect curves, the time courses of neuronal loss in cultures treated with PDGF-AA and PDGF-BB were very similar. In order compare the neuroprotective efficacy of PDGFs with other neurotrophic factors, we employed NGF and bFGF at concentrations previously shown to provide maximum protection against glucose deprivation-induced ncuronal injury in the same cell culture paradigm (Cheng and Mattson, 1991). During the first $24 \mathrm{hr}$ of glucose deprivation each of the growth factors supported the survival of $80-90 \%$ of the neurons. However, with longer periods of glucose deprivation, PDGF-AA and PDGF-BB were significantly more effective than $\mathrm{bFGF}$ and NGF in promoting neuronal survival (Fig. $1 B$ ).

Previous studies of neurotrophic factor-mediated protection against glucose deprivation-induced neuronal injury indicated that some neurotrophic factors (e.g., NGF) were able to "rescue" neurons even when administered many hours following glucose withdrawl, whereas other neurotrophic factors (e.g., bFGF) were effective only when administered prior to glucose withdrawl (Cheng and Mattson, 1991). We therefore administered PDGFs to hippocampal cultures at different time points relative to the onset of glucose deprivation, and then quantified neuronal survival $24 \mathrm{hr}$ following glucose withdrawl (Fig. 2). PDGF-AA and PDGF-BB afforded protection, at maximum efficacy, when added up to $4 \mathrm{hr}$ following the onset of glucose deprivation. However, when added 8 or $12 \mathrm{hr}$ following glucose withdrawl each of the PDGFs was largely ineffective in rescuing neurons (Fig. 2). In addition to protecting cultured embryonic rat hippocampal neurons against glucose deprivation-induced injury, each PDGF also protected cultured rat neocortical neurons and cultured mouse hippocampal neurons against glucose deprivation-induced injury (Fig. 3).

\section{Expression and localization of $P D G F$ receptors in hippocampal cell cultures}

Previous studies that examined the expression of PDGF receptor mRNA and protein in intact rat and mouse brain indicated that the PDGF $\alpha$-receptor was mainly expressed in glial cells, whereas the PDGF $\beta$-receptor was expressed in neurons (Smits et al.,

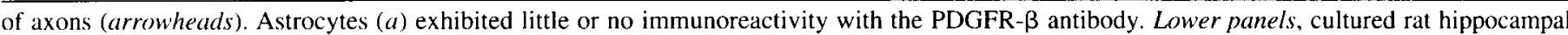

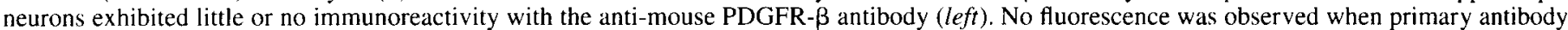
was not included in the immunostaining procedure $\left(-I^{\prime \prime} A b\right)$. 
1991; Pringle et al., 1992; Reddy and Pleasure, 1992; Hutchins and Zhang, 1994). Although neuronal responses to PDGF-BB might therefore be expected, our demonstration of neuroprotective actions of PDGF-AA suggested that the cultured hippocampal neurons may also express the PDGF $\alpha$-receptor. We therefore employed antibodies specific for either the $\alpha$ or $\beta$ PDGF receptor in Western blot and immunocytochemical studies to determine whether cultured embryonic hippocampal neurons expressed one or more of the PDGF receptors. Western blot analyses were performed on cell homogenates from mouse hippocampal cultures, rat hippocampal and neocortical cultures, and hippocampus and neocortex from adult rats (Fig. 4). A $180 \mathrm{kDa}$ protein band immunoreactive with PDGF $\alpha$-receptor antibody was seen in homogenates of cells cultured from mouse and rat hippocampus and rat neocortex; a band at the same molecular weight was barely detectable in homogenates from adult rat hippocampus and neocortex. A polyclonal antibody against mouse PDGF $\beta$-receptor detected a protein band of approximately 180 $\mathrm{kDa}$ in cell homogenates from cultured mouse hippocampus, hut not from rat hippocampus (Fig. 4) consistent with the species specificity of this particular PDGF $\beta$-receptor antibody.

Immunofluorescence confocal laser scanning microscopy was used to localize PDGF $\alpha$ - and $\beta$-receptor immunoreactivities in cultured mouse hippocampal cells (Fig. 5). Neurons were highly immunoreactive with antibodies to each of the PDGF receptors. PDGF $\alpha$-receptor immunoreactivity was present in the cell body and neurites, with particular concentration in the proximal regions of the axon (Fig. 5); previous studies showed that cultured embryonic hippocampal neurons elaborate one long process which is the axon and several short processes which are dendrites (Dotti et al., 1988; Mattson, 1989). The confocal optical section images indicated that the PDGF $\alpha$-receptor immunorcactivity was localized at high levels in the region of the plasma membrane (Fig. 5). Astrocytes also exhibited PDGF $\alpha$-receptor immunoreactivity which appeared to be localized in perinuclear regions and at the cell surface. Cultured mouse hippocampal neurons were higly immunoreactive with the PDGF $\beta$-receptor antibody with the immunoreactivity being concentrated in the cell body and proximal region of axons (Fig. 5). Cultured rat hippocampal neuron exhibited little or no immunoreactivity with the mouse PDGF $\beta$-receptor antibody, consistent with the Western blot analysis and the species specificity of this antibody. Astrocytes in mouse hippocampal cultures did not immunoreact with the the PDGF $\beta$-receptor antibody. No cellassociated fluorescence was observed when the primary antibody was eliminated from the immunostaining protocol. We also performed immunohistochemistry with PDGF $\alpha$ - and $\beta$-receptor antibodies in brain sections from adult mouse. In hippocampus the $\beta$-receptor immunoreactivity is concentrated in cell bodies and neurites of pyramidal neurons and granule cells, while $\alpha$-receptor immunoreactivity is weak or absent from neurons (data not shown).

PDGF-AA and PDGF-BB protect cullured hippocampal neurons against oxidative injury amd suppress accumulation of cellular peroxides

Because recent studies in several laboratories indicated that some neurotrophic factors can protect neurons against oxidative insults (see Mattson et al., 1993a, for review), we determined whether PDGFs might also enhance neuronal resistance to the toxicity of $\mathrm{FeSO}_{4}$ which kills cells by a hydroxyl radical-mediated mechanism (Zhang et al., 1993). Exposure of cultured rat
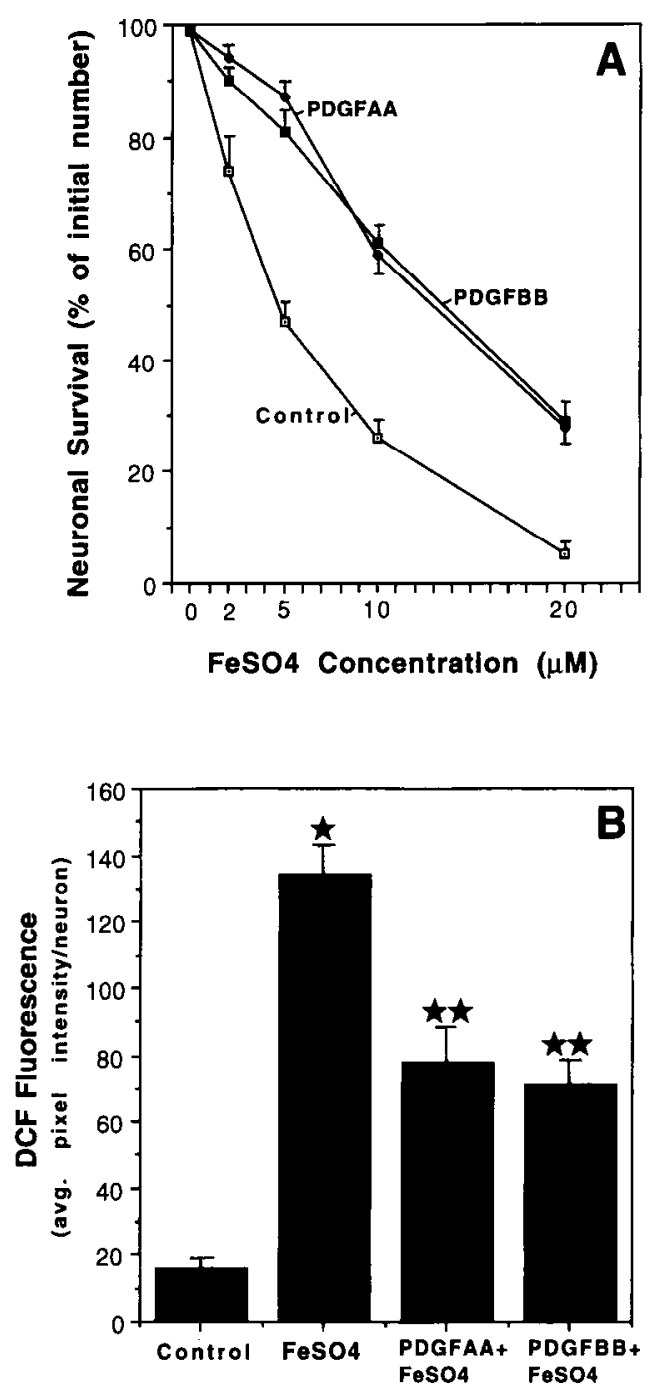

Figure 6. PDGFs protect hippocampal neurons against oxidative injury and suppress peroxide accumulation. $A$, Cultures were pretreated with saline (Control), or $100 \mathrm{ng} / \mathrm{ml}$ of PDGF-AA or PDGF-BB. Cultures were then exposed to the indicated concentrations of $\mathrm{FeSO}_{4}$ and neuronal survival was assessed $8 \mathrm{hr}$ later. Values represent the mean and SEM of determinations made in four separate cultures. Neuronal survival was significantly greater in cultures pretreated with PDGF-AA or PDGF-BB compared to control cultures exposed to $5 \mu \mathrm{M}(p<0.01)$, $10 \mu \mathrm{M}(p<0.01)$ or $20 \mu \mathrm{M}(p<0.05) \mathrm{FeSO}_{4}$. ANOVA with Scheffe's post-hoc test for pairwise comparisons, $B$. Cultures were either pretreated with saline, $100 \mathrm{ng} / \mathrm{ml}$ PDGF-AA or PDGF-BB and then exposed to vehicle (Control) or $10 \mu \mathrm{M} \mathrm{FeSO}$. Relative levels of peroxides (DCF fluorescence) were quantified $30 \mathrm{~min}$ following exposure to $\mathrm{FeSO}_{4}$. Values represent the mean and SEM of determinations made in 26-34 neurons in three separate cultures. ${ }^{*}, p<0.001$ compared to control value. ${ }^{*}, p<0.02$ compared to value for cells exposed to $\mathrm{FeSO}_{4}$ alone.

hippocampal neurons to increasing concentrations of $\mathrm{FeSO}_{4}(2-$ $20 \mu \mathrm{M})$ resulted in a concentration-dependent reduction in neuronal survival during a $8 \mathrm{hr}$ exposure period (Fig. 6A). The neurotoxicity of $\mathrm{FeSO}_{4}$ was significantly reduced in cultures pretreated for $24 \mathrm{hr}$ with $100 \mathrm{ng} / \mathrm{ml}$ of either PDGF-AA or PDGF$\mathrm{BB}$; protection was particularly striking with $\mathrm{FeSO}_{4}$ concentrations inducing an intermediate level of neuronal death. Fluorescence imaging methods, that employ the dye 2,7-dichlorofluorescin diacetate, can be used to quantify relative levels of peroxides in cultured neurons (Goodman and Mattson, 1994; Mattson et al., 
1995a). In the present study we used this approach to determine whether PDGFs would modify $\mathrm{FeSO}_{4}$-induced accumulation of peroxides in cultured rat hippocampal neurons. Cultures were pretreated for $30 \mathrm{hr}$ with $100 \mathrm{ng} / \mathrm{ml}$ of either PDGF-AA or PDGF-BB and were then exposed to $10 \mu \mathrm{M} \mathrm{FeSO}$ for $30 \mathrm{~min}$, at which time neuronal peroxide levels were quantified. In control cultures, $\mathrm{FeSO}_{4}$ induced a marked five- to eightfold increase in DCF fluorescence (Fig. $6 B$ ). In contrast, the level of DCF fluorescence induced by $\mathrm{FeSO}_{4}$ in $\mathrm{PDGF}$-preatreated neurons was significantly reduced (Figs. $6 B, 7$ ). $\mathrm{FeSO}_{4}$-induced peroxide accumulation occured throughout the neurons including in the cell bodies and neurites (Fig. 7). PDGF-AA and PDGF-BB also protected neurons in neocortical cell cultures against $\mathrm{FeSO}_{4}$ toxicity and suppressed $\mathrm{FeSO}_{4}$-induced accumulation of peroxides (data not shown).

\section{PDGFs induce protein tyrosine phosphorylation in hippocampal cell cultures}

In non-neural cells the PDGF receptors possess intrinsic tyrosine kinase activity and their activation results in a cascade of phosphorylation events beginning with phosphorylation of tyrosines on the PDGF receptor itself (Williams, 1989; Kanakaraj et al., 1991). We therefore determined whether PDGFs induced tyrosine phosphorylation of proteins in the hippocampal cell cultures. Cultures were exposed to $100 \mathrm{ng} / \mathrm{ml}$ of PDGF-AA or PDGF-BB for $1,2,5$, or $10 \mathrm{~min}$. Proteins in cell homogenates were then separated by SDS-PAGE, transferred to nitrocellulose sheets, and immunoblotted using a phosphotyrosine antibody (Fig. 8A). Both PDGF-AA and PDGF-BB induced a rapid increase in phosphotyrosine immunoreactivity of a protein band of approximately $180 \mathrm{kDa}$. The relative increase in tyrosine phosphorylation of the $180 \mathrm{kDa}$ protein appeared to peak within 2 min of exposure to a PDGF (Fig. 8B). Additional proteins also exhibited an increase in tyrosine phosphorylation in response to PDGF-AA and PDGF-BB including bands of approximately 42 and $44 \mathrm{kDa}$ in size (Fig. $8 A$ ).

\section{Effects of PDGFs on antioxidant enzyme activities}

Because PDGFs protected cultured hippocampal neurons against oxidative injury, and recent studies showed that neurotrophic factors can induce increases in activity levels of one or more antioxidant enzymes (Pan and Perez-Polo. 1993; Frim et al., 1994; Mattson et al., 1995a), it was of interest to determine whether PDGFs affected antioxidant enzyme activities in hippocampal cell cultures. Cultures were exposed to vehicle, 100 $\mathrm{ng} / \mathrm{ml}$ PDGF-AA, or $100 \mathrm{ng} / \mathrm{ml}$ PDGF-BB for $24 \mathrm{hr}$ and activities of $\mathrm{Cu} / \mathrm{Zn}-\mathrm{SOD}, \mathrm{Mn}-\mathrm{SOD}$, catalase, and glutathione peroxidase in cell homogenates were quantified. PDGF-AA induced a significant increase in activities of all four antioxidant enzymes, with a striking sixfold increase in catalase activity (Fig. 9). PDGF-BB increased catalase and glutathione peroxidase activities significantly, but did not significantly increase $\mathrm{Cu} / \mathrm{Zn}$ SOD or Mn-SOD activities.

\section{Discussion}

The present findings demonstrate that PDGFs can protect hippocampal and cortical neurons against metabolic and excitotoxic insults. The expression of both PDGF $\alpha$ - and $\beta$-receptors in neurons, the fact that both PDGF-AA and PDGF-BB were effective, and the differential effect of the two PDGFs on antioxidant enzyme activities strongly suggests that either $\alpha$ - or $\beta$-receptors can activate neuroprotective mechanisms. Each
PDGF dimer (PDGF-AA and PDGF-BB) stimulated antioxidant defense systems as demonstrated by the attenuation of $\mathrm{FeSO}_{4}$ induced peroxide accumulation in neurons pretreated with PDGFs, and by the induction of antioxidant enzyme activities. The concentration-effect curves for protection against glucose deprivation-induced neuronal injury by PDGF-AA and PDGF$B B$ were very similar with maximal effect being seen with concentrations of $100 \mathrm{ng} / \mathrm{ml}$ or greater, and half-maximal effect occuring with approximately $30 \mathrm{ng} / \mathrm{ml}$ of each PDGF. Previous studies have shown that PDGF-BB can induce all three combinations of receptor dimers (i.e., $\alpha \alpha, \beta \beta$, and $\alpha \beta$ ), while PDGFAA only induces $\alpha \alpha$ dimers (Seifert et al., 1989; Kanakaraj et al., 1991). Our data therefore suggest that activation of neuroprotective pathways by PDGF can be mediated by $\alpha \alpha$ receptor dimers. It is also possible that activation of $\beta \beta$ and $\alpha \beta$ dimers induce neuroprotective pathways, and that levels of expression of the different receptor dimer combinations is such that PDGF$\mathrm{AA}$ and PDGF-BB exhibit similar concentration-response curves. The observation that PDGF-AA stimulated increases in SOD activities, whereas PDGF-BB did not suggests that both $\alpha$ and $\beta$ receptors are involved in responses to PDGF in the hippocampal cell cultures.

Whereas previous in vivo studies of the adult rodent brain indicated that neurons express littlc or no PDGF $\alpha$-receptor (Pringle et al., 1992; Yeh et al., 1993), our Western blot and immunocytochemical analyses showed that cultured embryonic hippocampal and cortical neurons do express PDGF $\alpha$-receptors. It may therefore be the case that neurons express the $\alpha$-receptors during brain development (Reddy and Pleasure, 1992), or that they are induced as the result of an altered environment in cell culture. In agreement with previous data (Yeh et al., 1993) we observed PDGF $\alpha$-receptor immunoreactivity in astrocytes. Because astrocytes comprised approximately $10-20 \%$ of the cell population in our cultures, it is therefore possible that neuroprotective actions of PDGFs were mediated indirectly via actions on astrocytes. The presence of PDGF $\beta$-receptors in cultured hippocampal neurons documented in the present study is consistent with previous studies of developing and adult rodent brain (Smits et al., 1991; Hutchins and Zhang, 1994). Because astrocytes apparently lack the PDGF- $\beta$ receptor, it is likely that the neuroprotective actions of PDGF-BB are mediated by direct actions on the neurons.

The signal transduction pathways of PDGFs have been previously characterized in non-neuronal cells (Kanakaraj et al., 1989; Williams, 1989). Binding of PDGF dimers to receptors induces receptor dimerization, activation of intrinsic tyrosine kinase activity of the receptors, and association of cytoplasmic $\mathrm{SH} 2$ proteins which induce downstream kinase cascades. Consistent with a similar transduction pathway being operative in the primary neuronal cultures of the present study, we found that PDGF-AA and PDGF-BB rapidly increased tyrosine phosphorylation of several proteins including a band at $180 \mathrm{kDa}$. The molecular weight of PDGF receptors, which are known to undergo tryosine phosphorylation in response to activation by PDGFs, is $180 \mathrm{kDa}$. It is therefore possible that the $180 \mathrm{kDa}$ band represents a PDGF receptor(s), although this was not directly established. Because previous studies of neurotrophic factor actions have indicated involvement of tyrosine phosphorylation events in mediation of biological responses (Schlessinger and Ulrich, 1992; Mattson et al., 1995b), it seems likely that such tyrosine phosphorylation events mediate the neuroprotective actions of PDGFs. 

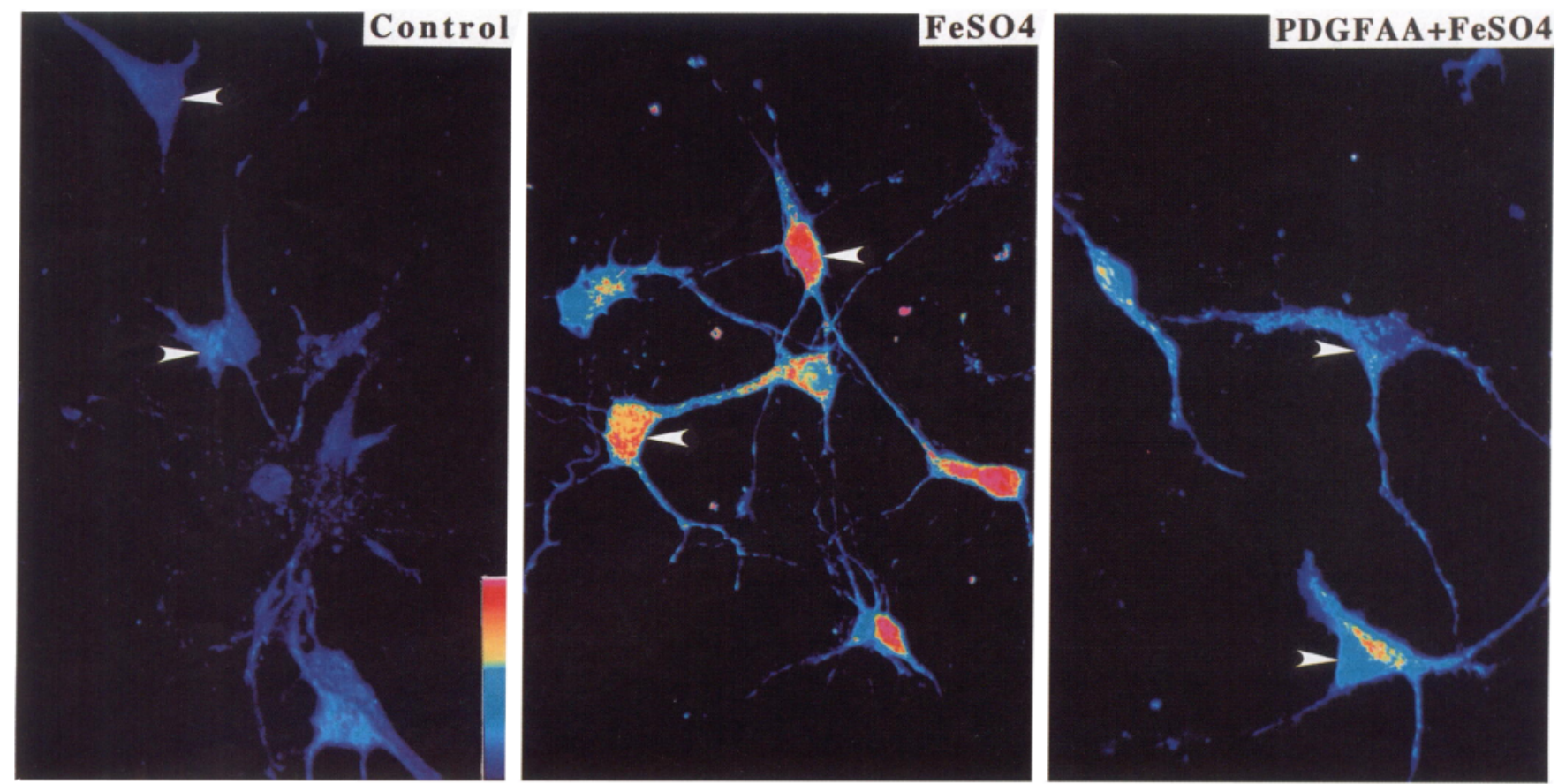

Figure 7. Iron-induced accumulation of cellular peroxides is suppressed in hippocampal neurons pretreated with PDGFs. Parallel cultures were pretreated for $24 \mathrm{hr}$ with saline or $100 \mathrm{ng} / \mathrm{ml}$ PDGF-AA and then exposed to $10 \mu \mathrm{M} \mathrm{FeSO}_{4}$ or vehicle (control) for 20 min. Confocal laser scanning microscope images of DCF fluorescence were then acquired. The images depict relative levels of cellular DCF fluorescence (peroxide levels) according to the color scale shown in the lower right corner of the left panel wherein colors represent pixel intensity (on a scale from 0 to 256 ; blue is the lowest level of fluorescence, and red the highest level). Note that $\mathrm{FeSO}_{4}$ induced accumilation of peroxides in neurons, which was considerably attenuated in cultures pretreated with PDGF-AA.

PDGFs protected neurons in both hippocampal and cortical cultures against glucose deprivation-induced injury. Moreover, within cultures from each brain region the PDGFs promoted the survival of essentially the total neuronal population. These findings suggest that the PDGFs have a broad range of target cell populations with regard to neuroprotective activities, and are consistent with the cellular localization of PDGF $\alpha$ - and $\beta$-receptor immunoreactivities which were present in essentially all neurons in the hippocampal and cortical cultures. As further evidence for widespread trophic actions of PDGFs in the brain are the data of Nikkhah et al. (1993) showing that PDGF promotes survival of mesencephalic neurons in culture. On the other hand, Nakao et al. (1995) recently reported that PDGF did not protect cultured sriatal neurons against glucose deprivation-induced death. However, in the latter study only one concentration of PDGF-AA and PDGF-BB was used ( $30 \mathrm{ng} / \mathrm{ml})$, and our doseresponse study indicates that this concentration was submaximally effective in protecting against glucose deprivation, at least in hippocampal cultures.

Several laboratories have recently reported that neurotrophic factors can increase antioxidant enzyme activities in various neural cell populations (e.g., Pan and Perez-Polo, 1993; Frim et al., 1994; Mattson et al., 1995b). We found that PDGF-AA and PDGF-BB increased, to varying degrees, levels of several antioxidant enzymes including $\mathrm{Cu} / \mathrm{Zn}-\mathrm{SOD}, \mathrm{Mn}-\mathrm{SOD}$, catalase, and glutathione peroxidase. Catalase and glutathione peroxidase are two enzymes that play a critical role in reducing levels of hydrogen peroxide and preventing formation of hydroxyl radical. SODs act to prevent accumulation of the potentially damaging superoxide anion. Therefore, it can be predicted that increases in activities of one or more of these enzymes would suppress accumulation of ROS and protect neurons against oxidative in- sults. Consistent with the latter possibility we found that ironinduced accumulation of peroxides in neurons was suppressed in cultures pretreated with PDGF-AA or PDGF-BB. We did not establish whether the enhancement of antioxidant enzyme activities by PDGFs resulted from induction of expression (transcriptional or translational regulation) of new enzymes, or perhaps modulation of activities of existing enzyme levels. However, in light of abundant evidence showing that neurotrophic factors (including PDGFs) can activate transcription factors, and essentially no precedence for regulation of antioxidant enzyme activity per se, it seems likely that PDGFs affect expression of the antioxidant enzymes. Further support for an effect of PDGFs on expression of antioxidant enzymes is the observation that pretreatment with PDGFs was required for protection against $\mathrm{FeSO}_{4}$ toxicity, and that protective efficacy against glucose deprivation rapidly declined when addition of PDGFs was delayed following the onset of glucose deprivation.

Metabolic impairment, oxidative processes and excitotoxicity are believed to contribute to the pathogenesis of both acute neurodegenerative conditions such as stroke and traumatic brain injury, and chronic age-related disorders including Alzheimer's disease, Parkinson's disease, and amyotrophic lateral sclerosis (see Beal, 1992; Mattson, 1994, for review). The glucose deprivation cell culture paradigm of energy failure employed in the present study has been extensively characterized in previous studies (Cheng and Mattson, 1991; Mattson et al., 1993c). The latter studies showed that glucose deprivation results in a delayed elevation of $\left[\mathrm{Ca}^{2+}\right]_{i}$ which resulted, in part, from activation of NMDA receptors by endogenous glutamate. Prolonged elevation of $\left[\mathrm{Ca}^{2+}\right]_{i}$ resulting from NMDA receptor activation promotes generation of reactive oxygen species including superoxide (Lafon-Cazal et al., 1993) and hydrogen peroxide (Matt- 


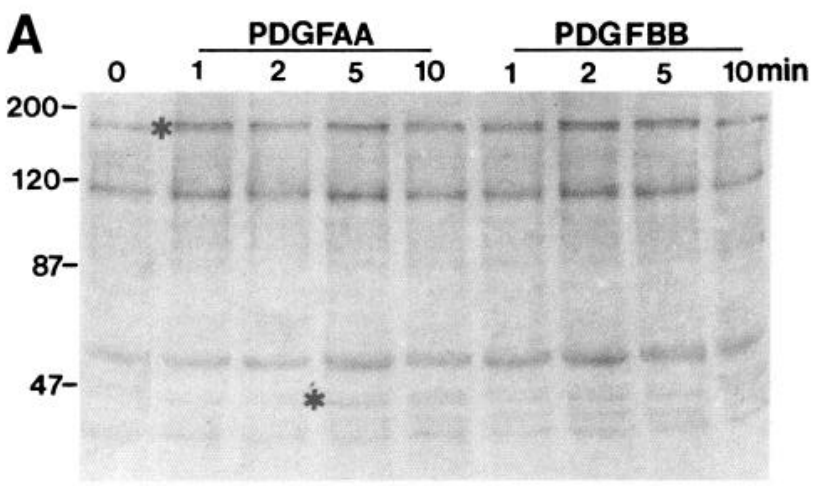

B

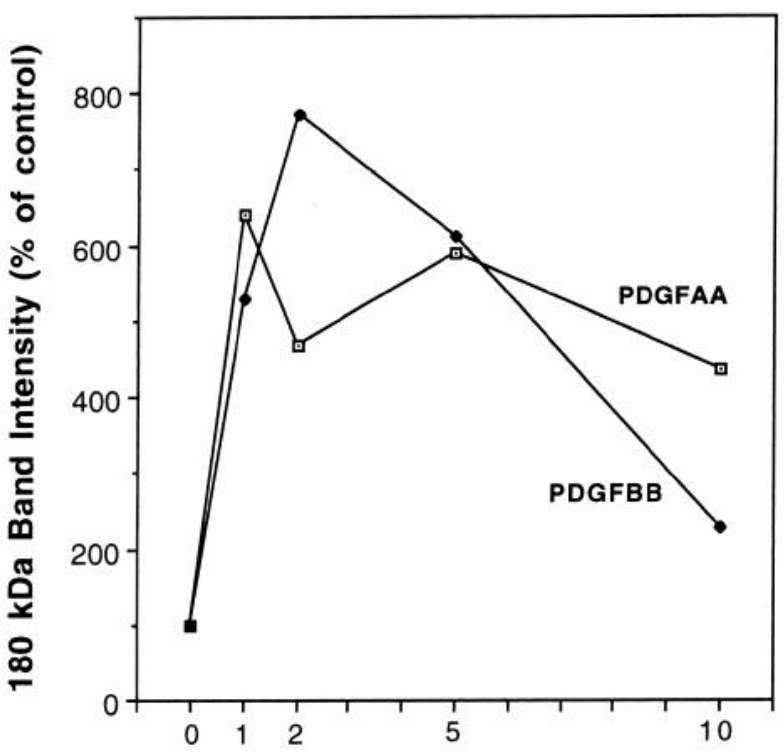

Time (min)

Figure 8. PDGFs induce tyrosine phosphorylation of a $180 \mathrm{kDa}$ protein. $A$, Cell homogenates ( $50 \mu \mathrm{g}$ protein/lane) were separated by SDSPAGE, transferred to a nitrocellulose sheet, and immunoreacted with antiphosphotyrosine antibody (clone 4G10). Homogenates were from control cultures ( 0 time point) and cultures exposed to either PDGFAA $(100 \mathrm{ng} / \mathrm{ml})$ or PDGF-BB $(100 \mathrm{ng} / \mathrm{ml})$ for $1,2,5$, or $10 \mathrm{~min}$. Each PDGF induced a rapid increase in phosphotyrosine immunoreactivity in a $180 \mathrm{kDa}$ band (upper *). Reactivity of two bands at approximately 42 and $44 \mathrm{kDa}$ also appeared to increase following exposure to PDGFs $($ lower $*$ ). B, Densitometric analysis of phosphotyrosine immunoreactivity of the $180 \mathrm{kDa}$ band following exposure to $100 \mathrm{ng} / \mathrm{ml}$ of either PDGF-AA or PDGF-BB. Similar results were obtained in two additional experiments.

son et al., 1995b). Antioxidants can attenuate excitotoxic insults (Dykens et al., 1987; Mattson et al., 1995b) indicating that oxyradicals play a major role in glutamate toxicity. A surprisingly broad array of neurotrophic factors have been shown to protect neurons against metabolic, excitotoxic and oxidative insults (see Mattson et al., 1993a, for review). For example, in the glucose deprivation paradigm in hippocampal cell cultures we found that bFGF, NGF, BDNF, NT-3, NT-4/5, and IGFs all reduced neuronal injury and death. Although the mechanism(s) whereby these neurotrophic factors protect neurons have not been elucidated,

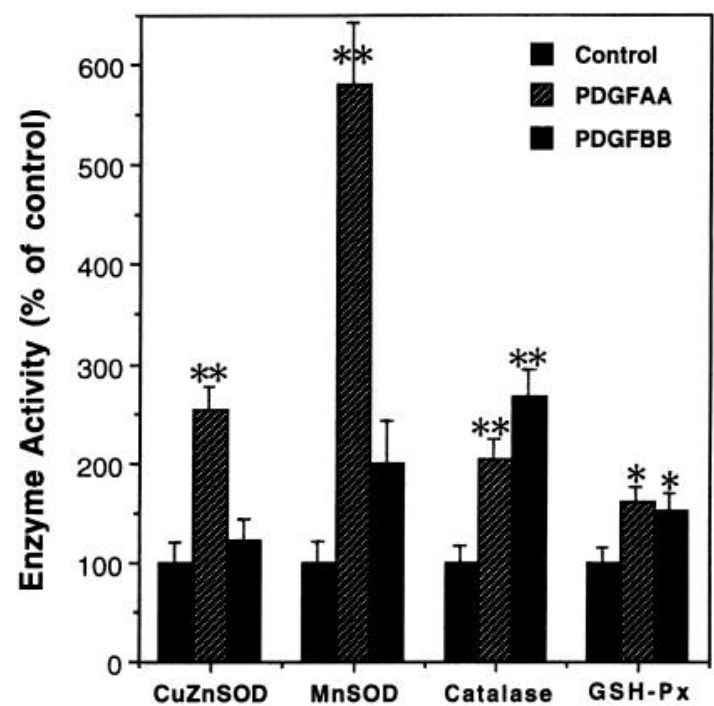

Figure 9. PDGFs increase antioxidant enzyme activities. Cultures were exposed for $24 \mathrm{hr}$ to vehicle (Control), PDGF-AA (100 ng/ml), or PDGF-BB $(100 \mathrm{ng} / \mathrm{ml})$. Antioxidant enzyme activities were determined in cell homogenates as described in Materials and Methods. Values are expressed as a percentage of activity in control cultures and represent the mean and SEM ( $n=3$ separate sets of cultures). Enzyme activities in control cultures were (units/mg protein): $\mathrm{Cu} / \mathrm{Zn}-\mathrm{SOD}, 2.26 \pm 0.4$ Mn-SOD, $0.4 \pm 0.1$; catalase, $0.6 \pm 0.1$; GSH-Px, $10.4 \pm 1.4 .^{*}, p<$ 0.05 compared to control. ${ }^{* *}, p<0.01$ compared to control.

each of them stabilizes cellular calcium homeostasis. In addition, bFGF, NGF, and BDNF were shown to suppress glutamate and iron-induced accumulation of peroxides (Mattson et al., 1995b). The present findings indicate that PDGFs represent another type of neurotrophic factor that can increase neuronal resistance to a variety of insults.

\section{References}

Beal FM (1992) Does impairment of energy metabolism result in excitotoxic neuronal death in neurodegenrative illnesses? Ann Neurol 31:119-130.

Bressler JP, Grotendorst GR, Levitov C, Hjelmeland LM (1985) Chemotaxis of rat brain astrocytes to platelet-derived growth factor. Brain Res 344:249-254.

Brown RH (1995) Amyotrophic lateral sclerosis: recent insights from genetics and transgenic mice. Cell 80:687-692.

Cheng B, Mattson MP (1991) NGF and bFGF protect rat and human central neurons against hypoglycemic damage by stabilizing calcium homeostasis. Neuron 7:1031-1041.

Cheng B, Mattson MP (1994) NT-3 and BDNF protect hippocampal, septal, and cortical neurons against metabolic compromise. Brain Res 640:56-67.

Cheng B, Christakos S, Mattson MP (1994) Tumor necrosis factors protect neurons against excitotoxic/metabolic insults and promote maintenance of calcium homeostasis. Neuron 12:139-153.

Claesson-Welsh L, Mammacher A, Westermark B, Heldin CH, Nister M (1988) Identification and structural analysis of the A type receptor for platelet-derived growth factor: similarities with the B type receptor. J Biol Chem 264:1742-1747.

Dotti CG, Sullivan CA, Banker GA (1988) The establishment of polarity by hippocampal neurons in culture. J Neurosci 8:1454-1468.

Dykens JA, Stern A, Trenkner E (1987) Mechanism of kainate toxicity to cerebellar neurons in vitro is analagous to reperfusion tissue injury. J Neurochem 49:1222-1228.

Frim DM, Wullner U, Beal MF, Isacson O (1994) Implanted NGFproducing fibroblasts induce catalase and modify ATP levels but do not affect glutamate receptor binding or NMDA receptor expression in the rat striatum. Exp Neurol 128:172-180.

Giacobini MM, Smits A, Funa K, Westermark B, Olson L (1992) Differential effects of platelet-derived growth factors on fetal hippocam- 
pal and cortical grafts: evidence from intraocular transplantation in rats. Neurosci Lett 136:227-231.

Goodman Y, Mattson MP (1994) Secreted forms of $\beta$-amyloid precursor protein protect hippo-campal neurons against amyloid $\beta$-peptideinduced oxidative injury. Exp Neurol 128:1-12.

Hall ED, Braughler JM, Yonkers PA, Smith SL, Linseman KL, Means ED, Scherch HM, Von Voigtlander PГ, Lahti RA, Jacobsen EJ (1991) U-78517F: a potent inhibitor of lipid peroxidation with activity in experimental brain injury and ischemia. J Pharmacol Exp Ther 258: $688-694$.

Heldin CH, Backstrom G, Ostman A, Hammacher A, Ronnstad L, Rubin K, Nister M, Westermark B (1989) Binding of different dimeric forms of PDGF to human fibroblasts: evidence for two different receptor types. EMBO J 7:1387-1393.

Hensley K. Carney JM. Mattson MP, Aksenova M, Harris M, Wu JF, Floyd RA, Butterfield DA (1994) A model for $\beta$-amyloid aggregation and neurotoxicity based on free radical generation by the peptide: relevance to Alzheimer's disease. Proc Natl Acad Sci USA 91:32703274.

Hutchins JB, Jefferson VE (1992) Developmental distribution of platelet-derived growth factor in the mouse central nervous system. Dev Brain Res 67:121-135.

Hutchins JB, Zhang X (1994) Platelet-derived growth factor (PDGF) receptors in the developing mouse optic pathway. Visual Neurosci $11: 33-40$.

Iihara K, Sasahara M, Hashimoto N, Uemura Y, Kikuchi H, Hazama F (1994) Ischemia induces the expression of the platelet-derived growth factor- $\mathbf{B}$ chain in neurons and brain macrophages in vivo. $\mathbf{J}$ Cereb Rlood Flow Metab 14:818-824.

Kanakaraj P, Raj S, Khan SA, Bishayee S (1991) Ligand-iduced interaction between a- and b-type platelet derived growth factor (PDGF) receptors: role of receptor heterodimers in kinase activation. Biochemistry $30: 1761-1767$.

Lafon-Cazal M, Pietri S, Culcasi M, Bockaert J (1993) NMDA-dependent superoxide production and neurotoxicity. Nature 364:535-537.

Matsui T, Heidaran M, Miki T, Popescu N, Lo Rochelle W, Draus M, Pierce J, Aaronson S (1989) Isolation of a novel receptor cDNA establishes the existence of two PDGF receptor genes. Science 243: 800-804.

Matsui T. Sano K. Tsukamoto T, Ito M, Takaishi T, Nakata H, Nakamura $H$, Chihara K (1993) Human neuroblastoma cells express $\alpha$ and $\beta$ platelet-derived growth factor receptors coupling with neurotrophic and chemotactic signaling. J Clin Invest 92:1153-1160.

Mattson MP (1994) Calcium and neuronal injury in Alzheimer's disease: contributions of $\beta$-amyloid precursor protein mismetabolism, free radicals, and metabolic compromise. Ann NY Acad Sci 747:5076.

Mattson MP, Murrain M, Guthrie PB, Kater SB (1989) Fibroblast growth factor and glutamate: opposing actions in the generation and degeneration of hippocampal neuroarchitecture. J Neurosci 9:37283740 .

Mattson MP, Cheng B, Smith-Swintosky VL (1993a) Growth factormediated protection from excitotoxicity and disturbances in calcium and free radical metabolism. Semin Neurosci 5:295-307.

Mattson MP, Kumar K, Cheng B, Wang H, Michaelis EK (1993b) Basic FGF regulates the expression of a functional $71 \mathrm{kDa}$ NMDA receptor protein that mediates calcium influx and neurotoxicity in cultured hippocampal neurons. J Neurosci 13:4575-4588.

Mattson MP, Zhang Y, Bose S (1993c) Growth factors prevent mitochondrial dysfunction, loss of calcium homeostasis and cell injury, but not ATP depletion in hippocampal neurons deprived of glucose. Exp Neurol 121:1-13.

Mattson MP, Barger SW, Begley JG, Mark RJ (1995a) Calcium, free radicals, and excitotoxic neuronal death in primary cell culture. Methods Cell Biol 46:187-216.

Mattson MP, Lovell MA, Furukawa K, Markesbery WR (1995b) Neu- rotrophic factors attenuate glutamate-induced accumulation of peroxides, elevation of $\left[\mathrm{Ca}^{2+}\right]_{i}$ and neurotoxicity, and increase antioxidant enzyme activities in hippocampal neurons. J Neurochem 65: $1740-1751$.

Mizuno Y (1984) Changes in superoxide dismutase, catalase, glutathione peroxidase and glutathione reductase activities and thibarbituric acid reactive product levels in early stages of development in dystrophic chickens. Exp Neurol 84:58-73.

Morrison RS (1986) Basic fibroblast growth factor supports the survival of cerebral cortical neurons in primary culture. Proc Natl Acad Sci USA 83:7537-7541.

Nakao N, Kokaia Z, Odin P, Lindvall O (1995) Protective effects of BDNF and NT-3 but not PDGF against hypoglycemic injury to cultured sriatal neurons. Exp Neurol 131:1-10.

Nikkhah G, Odin P, Smits A, Tingstrom A, Othberg A, Brundin P, Funa $\mathrm{K}$, Lindvall $\mathrm{O}$ (1993) Platelet-derived growth factor promotes survival of rat and human mesencephalic dopaminergic neurons in culture. Exp Brain Res 92:516-523.

Noble M, Murray K, Stroobant P, Waterfield MD, Riddle P (1988) Platelet-derived growth factor promotes division and motility and inhibits premature differentiation of oligodendrocyte/type-2 astrocyte progenitor cell. Nature 333:560-562.

Page B, Page M, Noel C (1993) A new fluorometric assay for cytotoxicity measurements in vitro. Int $\mathrm{J}$ Oncol $3: 473-476$.

Pan Z, Perez-Polo R (1993) Role of nerve growth factor in oxidant homeostasis: glutathione metabolism. J Neurochem 61:1713-1721.

Pringle NP, Mudhar HS, Collarini EJ, Kichardson WD (1942) PDGF receptors in the rat CNS: during late neurogenesis, PDGF alpha-receptor expression appears to be restricted to glial cells of the oligodendrocyte lineage. Development 115:535-551.

Raff MC, Lillien LE, Richardson WD, Burne JF, Noble MD (1988) Platelet-derived growth factor from astrocytes drives the clock that times oligodendrocyte development in culture. Nature 333:562-565.

Reddy UR, Pleasure D (1992) Expression of platelet-derived growth factor (PDGF) and PDGF receptor genes in the developing rat brain. J Neurosci Res 31:670-677.

Ross R, Raines EW, Bowen-Pope DF (1986) The biology of plateletderived growth factor. Ccll 46:155-169.

Sasahara M, Fries JWU, Raines EW, Gown AM, Westrum LE, Frosch MP, Bonthron DT, Ross R, Collins T (1991) PDGF B-chain in neurons of the central nervous system, posterior pituritary, and in a gransgenic model. Cell 64:217-227.

Sasahara A, Kott JN, Sasahara M, Raines EW, Ross R, Westrum LE (1992) Platelet-derived growth factor B-chain-like immunoreactivity in the developing and adult rat brain. Dev Brain Res 68:41-53.

Schlessinger J, Ulrich A (1992) Growth factor signaling by receptor tyrosine kinases. Neuron 9:383-391.

Seifert RA, Hart CE, Philips PE, Forstrom JW, Ross R, Murray M, Bowen-Pope DF (1989) Two different subunits associate to create isoform-specific platelet-derived growth factor receptors. J Biol Chem 264:8771-8778.

Smits A, Kato M, Westermark B, Nister M, Heldin CH, Funa K (1991) Neurotrophic activity of platelet-derived growth factor (PDGF): rat neuronal cells possess functional PDGF $\beta$-type receptors and respond to PDGF. Proc Natl Acad Sci USA 88:8159-8163.

Watson BD, Ginsberg MD (1989) Ischemic injury in the brain. Role of oxygen radical-mediated processes. Ann NY Acad Sci 559:269281.

Williams LT (1989) Signal transduction by the platelet-derived growth factor receptor. Science 243:1564-1570.

Yeh HJ, Silos-Santiago I, Wang YX, George RJ, Snider WD, Deuel It (1993) Developmental expression of the platelet-derived growth factor alpha-receptor gene in mammalian central nervous system. Proc Natl Acad Sci USA 90:1952-1956.

Zhang Y, Tatsuno T, Carney J, Mattson MP (1993) Basic FGF, NGF, and IGFs protect hippocampal neurons against iron-induced degeneration. J Cereb Blood Flow Metab 13:378-388. 